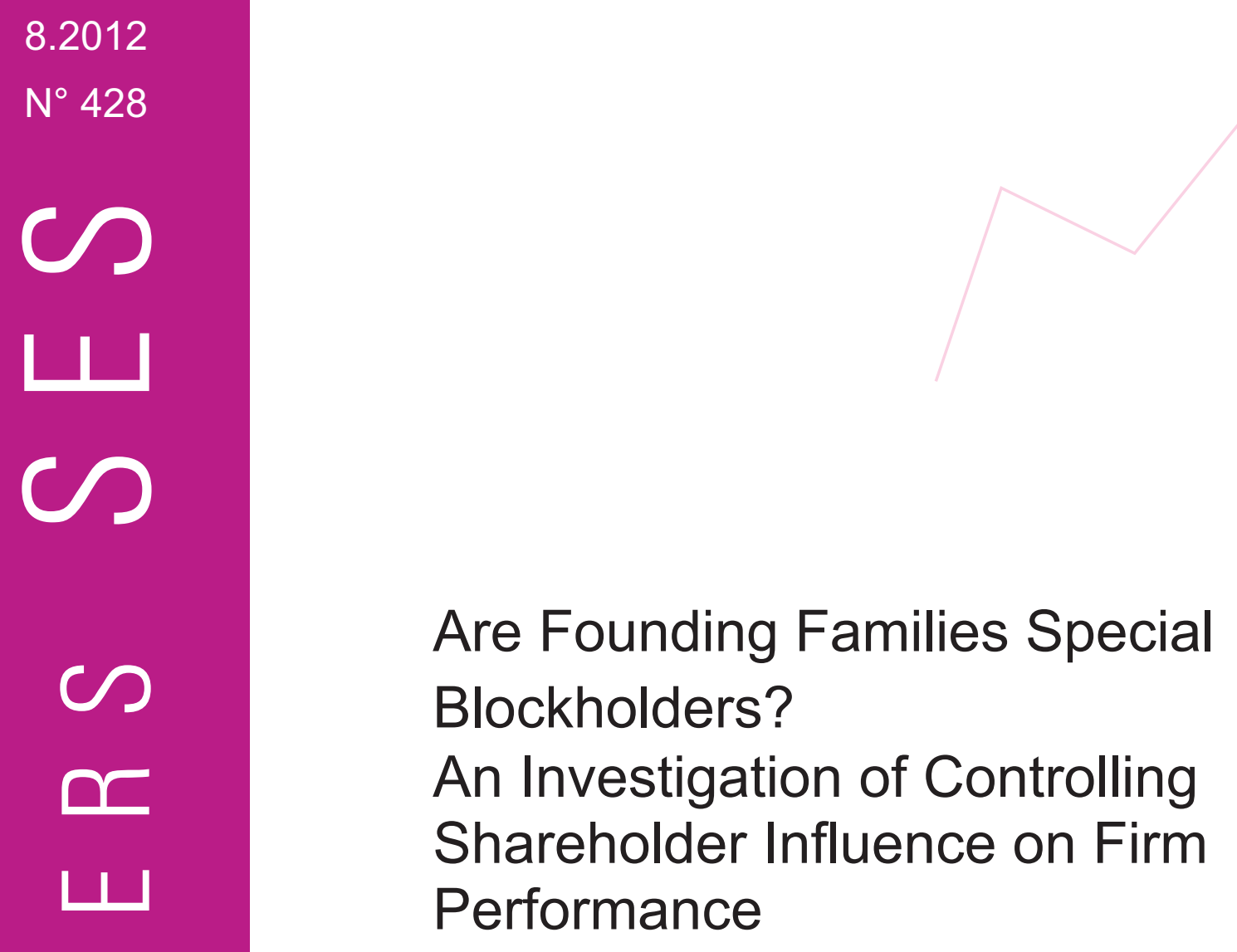

口

- Dušan Isakov and Jean-Philippe Weisskopf
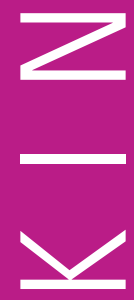

番

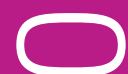

Faculté des Sciences Economioues et Sociales Wirtschafts- und Sozialwissenschaftliche Fakultät Université de Fribourg | Universität Freiburg 


\section{Are Founding Families Special Blockholders? An Investigation of Controlling Shareholder Influence on Firm Performance*}

Dušan Isakov ${ }^{\mathrm{a}}$, Jean-Philippe Weisskopf $\mathrm{f}^{\mathrm{a} \dagger}$

${ }^{\text {a }}$ University of Fribourg, Boulevard de Pérolles 90, CH-1700 Fribourg, Switzerland

We thank Gael Imad'eddine, Ron Masulis, Marc Schauten and David Stadelmann, seminar participants at the University of Zürich, conference participants at the 2009 FMA European Conference in Torino, the 2009 EFMA Conference in Milan, the 2009 Meeting of the French Finance Association in Paris, the 7th Corporate Finance Day in Antwerp, the 2010 Meeting of the Swiss Society of Economics and Statistics in Fribourg, the 2010 FMA European Conference in Hamburg, the 2010 FMA Asian Conference in Singapore for valuable comments and suggestions. We are responsible for all remaining errors.

${ }^{\dagger}$ Corresponding author. Tel.: +41 26300 8248, fax: +41 263009659.

E-mail addresses: dusan.isakov@unifr.ch, jean-philippe.weisskopf@unifr.ch 


\title{
Are Founding Families Special Blockholders? \\ An Investigation of Controlling Shareholder Influence on Firm \\ Performance
}

This version: April 25, 2012

\begin{abstract}
This paper examines how family and non-family ownership affects the performance of Swiss listed firms from 2003 to 2010. We distinguish between these two types of controlling shareholders since they have different objectives. We hypothesise that only family shareholders have a real incentive to reduce agency costs whereas non-family blockholders are similar to widely held companies. Our results show that family firms are more profitable and sometimes display better market valuations as opposed to companies that are widely held or have a non-family blockholder. We investigate the impact of different features of family firms on performance, and document that the generation of the family, active involvement of the family and contestability of family control play an important role.
\end{abstract}

JEL Classification: G3; G32

Keywords: founding family firm; active management; founder; ownership structure; firm performance; contestability 


\section{Introduction}

This paper examines how founding family ownership affects the market and accounting performance of public companies as compared to companies with other types of ownership structures. It pays special attention to three features of family ownership: the generation of the family, the degree of involvement of family members and the contestability of control in the firm. The paper relates to the recent stream of empirical literature on the effects of concentrated ownership on firm performance.

Until recently, the dominant paradigm in academic literature was that most public companies were widely held. The main challenge was to provide remedies to the classical agency problem present in such corporations. Berle and Means (1932) and later Jensen and Meckling (1976) are among the first to state that the separation between ownership and control can cause problems and incur important costs to shareholders. However, a series of recent studies on ownership structure reveals that in most markets a large number of listed companies do not have a widely dispersed ownership structure. In general, they have one or more large shareholders that can be categorised as families, states and other industrial or financial companies. Among these types of owners, family firms appear to be the most common form of ownership. In an international study, La Porta et al. (1999) find that $30 \%$ of firms are family controlled while 36\% are widely held. Faccio and Lang (2002) show that family firms are the predominant ownership structure in continental Europe wherein $44 \%$ of the companies are family controlled. They also show that firms with non-family blockholders represent $20 \%$ of the sample. Claessens et al. (2000) observe that in Asian countries approximately two-thirds of firms are owned by families or individuals. Even in the US, a market considered to have a majority of companies with a dispersed ownership, Anderson and Reeb (2003) establish that around 35\% of companies in the S\&P 500 are family controlled. This result has extensive repercussions on agency conflicts between owners and managers. This new view on ownership structure calls for a careful analysis of the consequences family ownership has on agency theory and company performance. Early literature on family firms finds that these firms seem to be more profitable and have a higher market valuation than non-family firms. It seems therefore that family ownership might be a way to reduce agency costs existing between managers and shareholders, and thus contribute to more value creation. The potential benefits associated with the presence of a majority shareholder are not new. Berle and Means (1932) already considered this possibility. Such a shareholder would have a far bigger incentive to control management since a large part of his 
wealth is invested in the company. As a result, every shareholder would benefit from this situation ${ }^{1}$.

The presence of a large shareholder can diminish or at least not aggravate the classical conflict between firm owners and managers, and thus reduces agency costs (agency costs I). However, the potential benefits of having a large shareholder in a company can be limited by the appearance of another type of agency problem. Large shareholders can use their power (in terms of votes and insider knowledge) to extract private benefits from the company. This will result in agency costs shifting from those between managers and owners to those between large shareholders and minority shareholders (agency costs II), which might be even more detrimental to minority shareholders. The extraction of private benefits is in the centre of this problem. Since the seminal paper of Grossman and Hart (1980), different authors have tried to quantify the magnitude of private benefits. Based on a sample of 39 markets worldwide, Dyck and Zingales (2004) observe that, on average, private benefits of control amount to $14 \%$ of equity value. These results indicate that agency problems between large and minority shareholders are a relevant issue. Problems are aggravated by the fact that many classic corporate governance mechanisms such as takeover threats or monitoring from institutional investors may become partly or completely ineffective especially if the controlling shareholder exercises a management position in the company or holds a majority stake. This position of knowledge and therefore power will also translate itself into the possibility to extract private benefits. From a theoretical point of view, it is not clear which of the two effects prevails in companies with a large shareholder. An increased monitoring of management that results in a better alignment of interests between owner and manager is positive, while the extraction of private benefits or entrenchment of a large shareholder is harmful to minority shareholders.

We believe that it is essential to consider the identity of the controlling shareholder and especially the distinction between family and non-family blockholders to determine which of the two effects prevails. Different types of blockholders have different incentives and motivations that will affect their way of perceiving the company and minority shareholders. Considering family firms, Arregle et al. (2007) suggest that families do care about their companies as they constitute the majority of their wealth and are part of their identity and

\footnotetext{
${ }^{1}$ An alternative view on the presence of a majority shareholder is proposed by Demsetz (1983). He argues that ownership concentration does not have an influence on firm value and that companies choose the form of ownership that minimises agency costs. This approach is further developed by Himmelberg et al. (1999) and Demsetz and Villalonga (2001).
} 
patrimony. This and the fact that the reputation, professionalism and perception of the family within its social environment are directly linked to the company works as a strong incentive to follow a long term strategy and behave in a way that is not purely self-centred (Ward (2004) and Miller and Le Breton-Miller (2005)). Thus, family members may expropriate less as their main interest is not primarily pecuniary (Corbetta and Salvato (2004)) and may control outside managers more thoroughly. It is therefore likely that agency costs I and II are of less importance in these firms. For companies with other types of large shareholders, the above-mentioned incentives are less stringent. For example in a company in which the state is a large shareholder, the person representing the state does not have as high an incentive to monitor managers as a family member. He himself is only an employee of the state and as such his own wealth is not directly affected by suboptimal decisions of company management. Moreover, this person will probably have other mandates that will ask for his time, and he will not be able to fully concentrate on a specific company. Furthermore, negative news will not impact him as much as it would a family that is closely linked to the company and for whom company reputation equals family reputation. We consequently posit that family companies will behave very differently from companies with non-family blockholders which should have an impact on firm performance. Despite the considerable research conducted in the field of family business, the distinction between the family and non-family blockholder has not attracted much attention yet.

In this paper, we try to fill this gap by using panel data over the period 2003-2010 for a comprehensive sample of companies listed on the Swiss exchange. The Swiss market present several important advantages for our empirical research in that its market capitalization is the 12th largest in the world and the fourth largest in Europe. This market includes multinationals such as ABB, Nestlé, Novartis, Richemont, Roche or Swatch, and offers a rich diversity of listed companies with interesting features for studying how firm performance is altered by ownership structure. Sample firms cover multiple industries: they range from a rather small and local market focus to large and multinational activities, and from young and growing to old and mature which are representative of a typical economy. The Swiss market is known for its high ownership concentration, with owners ranging from founding families or private investors to the State as well as other financial or industrial corporations. This makes the Swiss market ideal to investigate the influence of ownership structures on performance. Our data indicates a quite balanced panel of companies comprising approximately $37 \%$ widely held companies, $36 \%$ founding family firms and the remainder having a different blockholder 
type. Faccio and Lang (2002) show that in Western Europe there is no other country that has these balanced proportions; a majority are more heavily skewed towards family firms or widely held companies.

In view of the above, we examine whether founding family owners have a different impact on accounting and market-based performance as compared to companies with a different blockholder type. In our research, we consider Tobin's Q and Return on Assets (ROA) as performance measures. Employing a fixed effect model, we analyse the different characteristics of founding family firms to study the difference in performance. First, special emphasis is put on active management and generation of family members. The employment of family members as CEO or as Chairman should have an influence on performance, as a family member's decisions can have a strong impact on the company. It equally helps the family to either better control outside managers and therefore mitigate agency costs I, or to extract even more private benefits which would increase agency costs II. Generational differences might equally impact performance as descendants might have different motivations and values than founders and be more prone to expropriation. We also examine the distinction between companies with a single individual or with multiple founders or family members having a key role in the firm. Furthermore, we take a closer look at different measures of contestability of the family blockholder. Families that have total control of their company might increase agency costs II as nobody can contest their decisions, and they are free to do what suits them best.

Our main results show that founding family firms have a higher accounting-based performance but a similar valuation as compared to widely held companies and those with a non-family blockholder. However, firm characteristics have a significant impact on performance. A more detailed analysis reveals that it is especially firms at the founder stage that are more profitable and have significantly higher valuations. The benefits of family control are most pronounced for lone founders (feuds with other family members or founders are avoided) that are active in the firm. Furthermore, our results demonstrate that companies in which family control is not contestable show a better performance.

This study contributes to existing literature in three important ways. First, it expands knowledge in the fast rising field of family firms. This field has gained impetus since Anderson and Reeb (2003) but has so far focused mainly on market and accounting performance as compared to either non-family firms or widely held companies. With the exception of Maury (2006) and Andres (2008), the impact of blockholder identity on 
performance has not received much academic attention. Research on the link between identity and performance is important as it helps to draw inferences on how agency costs between controlling and minority shareholders can be reduced most effectively. Moreover, it sheds light onto family attributes that are associated with better firm performance.

Second, the paper adds new evidence to the literature on control contestability. Literature in this field mostly finds a reduced performance for companies that use dual-class shares or other control-enhancing mechanisms. Our study goes further and investigates not only dualclass structures but also family stakes and multiple blockholders to gauge whether contestability really is as positive as found or whether it also has a negative side.

Third, the article provides the characteristics and scope of ownership structure and their relation to performance of firms in Switzerland. Evidence in this field and on this market is non-existent to the best of our knowledge. Even outside Switzerland, the relation between blockholder identity, familyness and performance is not widely researched; the focus is rather on family performance versus non-family firms. This approach may be inappropriate since in most countries there are not only widely held companies or family companies but also a fraction of firms having non-family blockholders that are likely to behave differently from families.

The remainder of this paper is structured as follows. Section 2 reviews the relevant evidence relating family ownership to firm performance. Section 3 describes the sample and provides descriptive statistics. Section 4 introduces the methodology and presents results on the relationship between family ownership, other blockholders and firm performance. Section 5 focuses on robustness tests and section 6 summarises and concludes.

\section{Family firms and performance}

In the last ten years, empirical studies on the performance of family firms have started to emerge for different countries. To gauge whether agency costs are reduced, these articles on family firms mainly study Tobin's Q as a market-based indicator of performance and ROA or Return on Equity (ROE) as a profitability indicator.

The first studies on the topic were published for the US and Canadian markets. Among these studies, Anderson and Reeb (2003) find that family firms outperform their non-family counterparts in the S\&P 500. For the US market especially, family firms with a founding family member CEO are more profitable. Descendants as CEOs, however, do not seem to affect performance positively or negatively. From those first studies, it seems that active 
management by the family, especially by the founder, appear to be important for the firm to create value and to be more profitable. Consequently, these initial results were extended to different markets and analysed in more refined ways. Villalonga and Amit (2006) in a study on Fortune 500 companies extend Anderson and Reeb's analysis and find different results. They suggest focussing on the characteristics of family firms during the analysis of their performance. According to their results, firms in which the founder is active as CEO or chairman perform much better than those managed by descendants. A differentiation between ownership and control through control-enhancing mechanisms such as cross-holdings, pyramidal structures or dual-class shares also negatively affect firm performance in many cases. Miller et al. (2007) further distinguish family firms into those with lone founders and those considered true family firms with multiple family members involved. Controlling for different family definitions, they find evidence that family firm valuation is mainly driven by lone founder companies and that other family firms actually do not outperform. Fahlenbrach (2009) conducts an in-depth analysis on this founder phenomenon. . Examining companies in which founders still act as $\mathrm{CEO}$, he observes a higher valuation for these companies and a 10\% abnormal return as compared to a benchmark 4 factor model. Pérez-González (2006) scrutinizes CEO succession in family firms. His findings show evidence that inherited control has a negative impact on both firm valuation and profitability, which can be interpreted as a sign of nepotism if founders put their heirs in charge of the firm instead of an outside CEO. This is especially the case for firms in which the descendant did not attend a selective college. Contrary to Anderson and Reeb, it shows that it is wrong to assume that family firms per se outperform non-family firms. Depending on the characteristics of the firm, the result may differ significantly. Companies at the founder stage are the main driver of such an outperformance in family firms. King and Santor (2008) study the Canadian market as it comprises similar regulatory structures as those of the US but has a more concentrated ownership, an attribute which makes it ideal for studies on family companies. They suggest that family firms are not bad as such in Canada. It is specifically the use of control-enhancing mechanisms such as dual-class shares that destroy value, and not the presence of a family. Those with a single share class show a market performance similar to that of other companies, but with a higher ROA. Those with more than one share class have similar ROA but a worse market performance measured by Tobin's Q. The advances made on this topic with regard to North American markets and the realisation that ownership concentration and 
family shareholder presence is even more pronounced in continental Europe has led to the investigation of this topic outside the US and Canada.

As far as Western Europe is concerned, two cross-country studies by Barontini and Caprio (2006) and Maury (2006) using panel data observe that family firms may have a higher market valuation calculated as Tobin's $\mathrm{Q}$ and a higher profitability under certain conditions. Barontini and Caprio find similarities to the study by Villalonga and Amit confirming that specifically, family firms with a founder CEO perform better than other firms. However, compared to the evidence obtained for the US, the performance of descendant-owned firms appears to be different. If the descendant family member only assumes a non-executive position, the firm still outperforms non-family firms; if he is CEO, it performs as well as nonfamily firms; and only if the family takes up no active role at all, it performs worse. Maury, on the other side, indicates that active management only enhances profitability but does not have a real impact on firm valuation. He outlines that ownership and control level are drivers for market and accounting performance. Observing a nonlinear relation between control and performance, he suggests that benefits from family ownership fade with higher level of control. Market valuation expressed as Tobin's $Q$ is highest for firms with the family having a low control level. This may be interpreted as a sign of increased family opportunism and extraction of private benefits if the family gains too much power. On the contrary, profitability increases with family control level, which shows that family management improves company efficiency but minority shareholders cannot really profit from it.

Evidence on single European countries presents similar findings. The first studies examined Scandinavian markets. Cronqvist and Nilsson (2003) observe that Swedish family firms frequently use dual-class shares and exercise their controlling position to pursue suboptimal investment decisions (thus having a low ROA) and entrench themselves. This produces a valuation discount and results in the lowest firm value on the market. Bennedsen et al. (2007) study the Danish market and look specifically at company valuations and CEO identity. Their evidence shows that family CEO have a negative impact on firm valuation while the appointment of professional outside CEO is beneficial. These initial negative findings on family firms were followed by studies on other countries that find a more positive link between family characteristics and firm value. Sraer and Thesmar (2007) research French-listed family firms and report that family firms outperform widely held companies, independent of a founder, descendant or outsider managing the firm. They additionally find that founders account for most of the outperformance, and propose different reasons linked to 
labour force, wages and productivity to explain why the respective management type delivers superior performance. In a study on German listed firms, Andres (2008) finds that family firms are more profitable than both widely held companies and companies with other blockholder types. In line with evidence found in Sraer and Thesmar (2007), he finds that performance, in particular, increases with a founding family member actively managing the company and that founder-managed companies show the strongest effect on performance.

On the whole, evidence suggests that family firms have an impact on firm performance for different reasons. The nature of the impact very much depends on the characteristics of the family and its ties to the company. The vast majority of these studies, with the notable exceptions of Andres (2008) and Maury (2006), analyse samples that compare family firms with non-family firms. Although this yields interesting insights, it does not provide the complete picture as non-family firms are not uniform. A widely held company will be governed differently from a company with a non-family blockholder. This distinction should be considered when examining the performance of family companies.

\section{Data and variables}

\subsection{Sample}

The sample includes all companies listed on the Swiss Exchange between 2003 and 2010. First, we consider all companies that constitute the broadest stock index in Switzerland, the Swiss Performance Index. This restriction allows us to eliminate companies with a very low free float, open-end funds or companies that only have a secondary listing on the Swiss Exchange. The companies must have been part of this index for at least one year to be included in the study. Next, all financials (ICB 8000) are discarded; a stronger regulation of financial companies complicates the calculation of a comparable and correct Tobin's $\mathrm{Q}$ and ROA. The sample period starts in 2003 because the publication of data on corporate governance for Swiss companies was not mandatory before this year. The period ends in 2010 as it is the most recent fiscal year for which companies have reported their financial results. The final sample includes 185 companies (1193 firm-year observations). ${ }^{2}$

As the research is focused on founding family firms, it is critical to have reliable information on the ownership structure of Swiss companies. This is mostly achieved through hand-collecting information from different sources. First, the data is collected from

\footnotetext{
${ }^{2}$ In the regression, we can only use 1183 observations since we do not have complete information for 10 firmyear observations.
} 
companies' annual reports and classified by shareholder type, such as widely held firms, companies with an individual shareholder, state-owned firms, companies with widely held industrial or financial corporations as an ultimate blockholder, and miscellaneous. Second, firms which report one or more individuals as blockholders are divided into founding family firms and firms with a private investor. If no clear evidence about the ultimate blockholder was obtained from annual reports, additional information was taken from Swiss stock guides, newspaper articles, corporate homepages or the commercial register. Data on managerial positions by family members and generational issues was retrieved by applying an equivalent procedure.

In concluding the process, all data on corporate governance and ownership is finally merged with accounting and financial data from Thomson Reuters Worldscope and Datastream. This allows for reliable data and information on a vast array of companies from different industries, of different sizes and age and having different ownership structures.

\subsection{Ownership variables}

Following extant literature on family firms and blockholders, a company is defined as being widely held if no shareholder holds more than $20 \%$ of ultimate voting rights (see among others Villalonga and Amit (2006), Sraer and Thesmar (2007)). Although a threshold of $20 \%$ may seem low, there exists a widely accepted view that due to generally low annual meeting attendance and active representation of blockholders either as chairman of the board or CEO in many companies, it is sufficient for having an influence on company policies and management.

The term founding family is used for one or more individuals or families that founded a company or, when this is not the case, must have been an investor over a long period of time and have shaped the company in a substantial way. For example, the Hayek family controls the Swatch Group, a major watch manufacturer. It has held approximately $40 \%$ of the shares for most of the last 20 years. Both Mr Hayek senior (until his death in 2010) and junior as well as other family members are active in the firm and have shaped the company to make it what it is today. Although not controlled by the founding family, Swatch can be considered a family firm. This restriction ensures that firms with individuals who are pure financial investors are not mistaken for family firms. Founding family firms may also have been established by more than one individual or family (for example the Hoffmann and Oeri families for Roche or the Rihs brothers and Beda Diethelm for Sonova). 
A non-founding family blockholder may have various identities. In the case of Swiss state ownership, it may not only refer to the Swiss Federal Government but also to regional (cantonal) and municipal government entities. For example, Zurich airport is owned by the region and city of Zurich. Widely held industrial and financial corporations in this context are companies that themselves do not have a dominant shareholder, for example, large stakes held by UBS or Credit Suisse. Miscellaneous includes blockholders that could not be classified into any other category. It is mostly composed of foundations, cooperatives or private pension funds. Contrary to these rather straightforward classifications, firms with private investors as large shareholders need more scrutiny. A private investor is defined as one or more individuals that have neither founded the company nor shaped it in a substantial way over the years. In case there is more than one private individual, it must clearly be stated that such investors have an agreement to vote together. For example, OC Oerlikon (formerly Unaxis) has seen changes to its shareholder structure all along the sample period. In 2005, two Austrian investors bought a major stake in the company, pushed the founding family completely out and planned to transform it into a European General Electric. After different feuds and economic and political problems, they gradually reduced their stakes by selling their holdings to a Russian billionaire. Neither of these investors founded the company and neither will stay in it for a considerable period of time, thereby making them private investors. This example shows that it is important to distinguish between the two ownership types, as motivations and values will strongly differ between a founding family and private investors who are only in the company to make a quick profit and then leave. Private investors will also differ from other non-family blockholders as they are more likely to reduce agency costs I (more incentives to control managers) but are more prone to agency costs II (more incentives to extract private benefits). Corresponding with these definitions and appearing in Tables 1 and 2, we have created different dummy variables that equal one if a company belongs to a specific category and zero otherwise. Overall, the sample consists of 185 companies and 1193 firm-year observations that are composed of 431 founding family firm years, 323 firm years with a non-family blockholder and 439 widely held firm years.

In addition, the dummy for founding family firms is divided into several sub-groups. First, a distinction is made between founding families owning the majority of voting rights (i.e. more than $50 \%$ of votes) or only a controlling stake between $20 \%$ and $50 \%$. Several studies have shown that family firm characteristics, and here especially the active involvement of a family member, or generational issues may have an important impact on firm performance 
and policy (e.g. Pérez-González (2006), Villalonga and Amit (2006) or Bennedsen et al. (2007)). Considering these findings, founding family firms have further been categorised into groups depending on the active position and generation of a family member. We create dummies on the basis of the fact that the CEO or chairman of the board is a family member or an outsider. In case it is a family member, we further distinguish between founder and descendant. We also examine the impact of single or multiple founders or family members in a company. Consequently, we build dummies for family companies having a lone founder (i.e. a single person) or multiple individuals (i.e. multiple founders or family members involved). Finally, the founding family dummy is decomposed to test the contestability of the family stake. We first distinguish between family firms with and without dual-class shares and then on the contestability of family control. The control is assumed to be contestable and the dummy takes the value 1 , if the family holds less than $50 \%$ of voting rights and a second blockholder exists to counterbalance its power.

\subsection{Performance and control variables}

Market and accounting performance is measured as Tobin's Q and ROA, respectively. Tobin's Q is defined as (market value of common equity + book value of total assets - book value of common equity) divided by book value of total assets. In case of companies with multiple listed share classes, the value of every single share class is added. Tobin's $Q$ is a forward-looking measure that reflects the market valuation of a firm's assets (relative to book value). ROA is calculated as earnings before interest and taxes divided by total assets. ROA is a backward-looking accounting measure that represents profitability or productivity.

The following variables used to control for industry- and firm-specific characteristics, which are standard in the literature, are used for each year. Firm size is measured as the logarithm of total assets; age is defined as the logarithm of years since the foundation of the firm; leverage is measured as total book value of debt/common shareholder's equity; investment intensity is capex/PPE; growth opportunities are represented by the increase in one-year sales; and risk by the beta of monthly returns of the preceding 60 months. Industry is defined according to the ICB classification.

\subsection{Descriptive statistics}

Following the above-mentioned definitions, founding family firms represent on average $36 \%$ of companies in the sample over the period 2003-2010;37\% are widely held companies while $27 \%$ are owned by non-family blockholders (corporations, government entities, 
miscellaneous). These numbers remain very stable over the period examined with only very few companies changing categories. Our results are in line with Faccio and Lang (2002) who find that ownership is concentrated in Europe with only $37 \%$ of widely held companies and $44 \%$ family companies. Their study also shows that in Switzerland ownership types, widespread ownership, family firms and non-family blockholders, are the most balanced in Western European countries with proportions of $28 \%, 48 \%$ and $24 \%$, respectively. ${ }^{3}$

Table 1 illustrates that family firms are included in $85 \%$ of all industries that make up the Swiss Performance Index. Family firms are the sole ownership type in three industries, namely, Leisure Goods, Beverages and Automobiles and Parts. There is no family firm in the underrepresented industries, Oil and Gas Producers, Food and Drug Retailers, Fixed Line Telecommunications and Electricity.

[Insert Table 1 about here]

Table 2 shows descriptive statistics for different variables used in the following analysis. Average Tobin's Q is 1.66 while average ROA is $6.58 \%$. The firms in the sample have an average size and age of 3.60 billion Swiss francs and 70 years, respectively. Annual sales growth is $6.84 \%$ and leverage $54 \%$. The difference between voting and ownership rights for controlling shareholders amounts to $5 \%$ on average. As expected, the average beta is very close to market beta with a value of 1.02 . Investment intensity is at a level of $19 \%$. Family firms represent $36 \%$ of the sample companies. About $36 \%(0.13 / 0.36)$ of founding family companies are at the founder stage and $61 \%(0.22 / 0.36)$ have a family holding a majority (i.e. at least $50 \%$ of voting rights) of shares. $37 \%$ of sample companies have a widespread ownership; $27 \%$ have a non-family blockholder that is either a private investor $(41 \%)$, the state $(20 \%)$, another company $(27 \%)$ or miscellaneous $(12 \%)$.

[Insert Table 2 about here]

Table 3 shows results of the univariate analysis for different ownership types in the sample by testing difference of means and performing a Wilcoxon-Mann-Whitney test on medians between different ownership types. Tobin's Q is not significantly different between widely

\footnotetext{
${ }^{3}$ The difference in proportion for family firms is due to the distinction between founding families and private investors in this study.
} 
held and founding family companies. It is however significantly lower in companies with a non-family blockholder than in the two aforementioned firm types. ROA is significantly higher in family firms than in companies with other ownership structures. These initial results seem to show that different blockholder types and ownership structures in general lead to divergent findings and deserve further investigation.

\section{[Insert Table 3 about here]}

The difference (wedge) between cash flow and voting rights through multiple share classes is $11 \%$ for founding family firms but only $3 \%$ for non-family blockholder firms. This is a clear sign of family firms trying to preserve control in their companies ${ }^{4}$. Kunz (2002) states that the number of companies with dual-class shares has decreased over the last 20 years in Switzerland. This shows that families and companies are now more inclined to follow the one-share-one-vote principle. However, pressure from shareholders to change the voting structure has been less successful in companies in which a family is present. Leverage is significantly higher in companies with a non-family blockholder, while beta is significantly higher in widely held companies than the others.

\section{Empirical results}

We use a regression model with dummies for each year and industry under consideration to assess the relation between firm performance (Tobin's Q, ROA) on the one side and founding family control on the other. The basic form of the regression model we estimate is

$$
\text { Performance }_{\mathrm{i}, \mathrm{j}, \mathrm{t}}=\alpha_{\mathrm{i}}+\phi_{\mathrm{i}} \text { familyfirm }_{\mathrm{j}, \mathrm{t}}+\eta_{\mathrm{i}} \text { controlvariables }+\delta_{\mathrm{i}} \text { industries }+\gamma_{\mathrm{i}} \text { years }+\varepsilon_{\mathrm{i}, \mathrm{j}, \mathrm{t}}
$$

where $i$ equals the different performance measures for each company $j$ at year $t$. Family firm is a dummy variable which takes account of the different founding family firm characteristics. Control variables include firm size, firm age, leverage, sales growth, investment intensity, beta and a dummy variable to identify widely held firms. Industries and

\footnotetext{
${ }^{4}$ We find that Swiss firms essentially use dual-class shares as a control-enhancing mechanism. This is in line with results reported in Faccio and Lang (2002).
} 
years are dummy variables equalling 1 for the respective industry and year observed, and zero otherwise.

\subsection{Family firm performance}

Table 4 examines market and accounting performance of founding family firms, widely held companies and firms with non-family blockholders. Column 1 and 3 take Tobin's Q and ROA as a measure of market and accounting performance, respectively, with founding family being a dummy equalling 1 if the firm has a founding family as blockholder. The positive and significant coefficient for ROA suggests that family firms display a higher accounting performance than companies with non-family blockholders. However, this superior profitability is not reflected in valuation as Tobin's Q does not significantly differ. Widely held companies neither display significant coefficients for Tobin's Q nor for ROA, which signals that a non-family blockholder does not reduce agency costs I or that these costs are compensated by agency costs II.

[Insert Table 4 about here]

Columns 2 and 4 complement the evidence on the performance of family firms for better understanding of the drivers of the positive relation between family firms and ROA and the insignificant Tobin's Q coefficient. We study the possibility of a nonlinear relation between family control and firm performance. Previous studies (e.g. Anderson and Reeb (2003) and Morck et al. (1988)) show that a nonlinear relation might exist if incentives of the shareholder change with an increased ownership stake. The founding family dummy is consequently changed into a continuous family ownership and squared family ownership variable (i.e. $\%$ of voting rights). Using both Tobin's Q and ROA, we find a nonlinear relation. For Tobin's Q, the highest value is reached at an inflection point of $39.5 \%$, while the profitability tapers off at a level of $49.9 \%$ for ROA.

Overall results suggest that profitability is higher for founding family firms. Valuation does not seem to be uniformly better across family companies. The market seems to appreciate the benefits of family shareholdings but only up to a level at which the family does not have total control of the company. Beyond this level, the family becomes too powerful, expropriation becomes more likely and investors get wary. 


\subsection{Active family involvement}

Earlier results on family firm performance show that it would be wrong to judge family firms as such without further differentiation. Evidence was found that performance might depend on a variety of other characteristics, and in our study, especially on the involvement of family members in the company. Studies on the generation and position a family member takes in the company have yielded different results. Villalonga and Amit (2006) find that family firms with founder-CEO perform better whereas those with descendant-CEO underperform significantly compared to widely held companies. Barontini and Caprio (2006) show that descendant-stage firms only perform well if descendants do not take an active role in the company. On the other hand, Sraer and Thesmar (2007) suggest that a descendant-CEO does not perform worse than a founder-CEO.

[Insert Table 5 about here]

Table 5 shows results for companies with active or passive family members. Columns 1 and 4 show that both market and accounting performance are higher in companies in which a family member is active in management or on the board. This suggests that a family member possessing the ability to influence management and a direct way to influence company policies and strategies is essential. It equally shows that an active family member is able to generate a company dynamic that goes beyond what a non-family blockholder can achieve. Market valuation is especially driven by active founders. These are the only case for which a positive and significant relation exists between family ownership and Tobin's Q, thereby suggesting that the market perceives a company founder as very positive and able to generate above-average results. This can be due to superior management skills, values or simply due to good ideas on policies or products. Companies in which no family member or descendants are active do not display a higher valuation than non-family blockholder firms. Although these firms are still more profitable than non-family firms, investors seem to mistrust these types of companies more than those with other blockholders.

Profitability, on the other hand, is positive and significant across all types of family firms. Especially, companies in which family members have total control over management, the board outperforms strongly. This suggests that either agency costs I are non-existent as the owner is the manager or that superior profitability can only be achieved if the family has the power to push through its ideas and work practices without having to make concessions to 
outside managers. Companies in which only the founder or the founder and a descendant are active have the highest profitability. Once again it seems that the founder has some superior knowledge or idea. Though descendants outperform, they do more so in combination with the founder, which again signals a strong founder effect.

Overall it seems that family members, especially company founders, have superior skills and incentives that enhance a firm's value above the gains that result from a reduction of agency costs from having a blockholder present. It gives a clear indication that it is not only important to have a blockholder to reduce agency costs I but also to have an individual who gives an additional edge to the company he manages.

\subsection{Founders, lone founders and descendants}

Family firm performance may be affected by many factors. One of them is linked to the power a founder has in his company. If he is alone, he might be able to manage the company in a way he believes is appropriate without the interference of other founders or family members. If the vision, knowledge or management style of the founder is what drives the company forward, then he, being a lone founder, might have a positive impact on performance. On the other hand, having multiple founders or family members involved in the company may lead to feuds or sub-optimal decision-making to satisfy family members rather than shareholders in general. A study of the Times Mirror Company by DeAngelo and DeAngelo (2000) clearly shows the negative effects such a situation can produce.

\section{[Insert Table 6 about here]}

Results in Table 6 confirm that family companies have a higher accounting performance and sometimes a better market valuation than those firms with other types of ownership structures. It is, however, preferable to have a single person in a family firm. Both market and accounting performance are enhanced when there is only a lone founder or descendant (i.e. no multiple founders or family members hold stocks or are actively involved) in the company. It further seems that although firms at the descendant stage perform better than those with nonfamily blockholders it is primarily those at the founder stage that clearly outperform and in which investors trust the most. 


\subsection{Family firm performance and contestability}

From the perspective of performance, especially valuation, contestability of the family might become important. Market participants might prefer to have the benefits of a family but not at any price. The presence of a family whose control is contestable in some way might help alleviate concerns. Table 7 therefore looks at several contestability measures. First it looks at the presence of dual-class shares. This control-enhancing mechanism can be used to lock in control of the company. Second it looks whether the family holds a majority of voting rights and therefore cannot be contested in any way. Third we construct a contestability dummy that equals 1 if a family holds between 20 and $50 \%$ of shares and the company has a second blockholder that might challenge family decisions.

[Insert Table 7 about here]

The use of multiple shares classes in family firms is perceived in a positive way by investors. Not only accounting but also market performance is higher for companies using dual-class shares. This implies that the use of multiple share classes is not negative as such. It seems that they are used only to lock in control and not to expropriate minority shareholders. All other measures of contestability do not yield significantly different results from a market perspective. From the viewpoint of profitability, results change significantly. Family firms whose control is not contestable display a higher ROA throughout all contestability measures. This indicates that a family is only able to generate a higher ROA if there is no outside pressure.

\section{Robustness tests}

A well-known potential problem when assessing the performance of family firms is endogeneity, or more specifically a reverse causality issue. It can be argued that it is not the ownership structure that yields a better performance of family firms but that, on the contrary, good performance influences the decision if a company is family controlled or not. The possibility exists that a family will only stay on as a shareholder or pass on the company if it performs well, but sell it if it underperforms. However, there are a number of observations that seem to indicate that this problem is not serious in our case. We observe that during the sample period, only nine companies changed their ownership structure from family firm to non-family firm. In four cases, the family owner lowered his stake under the $20 \%$ threshold to 
about $15-19 \%$ and kept an active position as CEO, chairman or even both. In two other cases, the company was taken over by another a private person who plans to hold on to the shares for a longer period of time. In two cases, the company became a widely held company, and in another one, the family decided to give up its stake to avoid a control fight with another investor that was trying to take over the company. Thus, it cannot be argued that families departed due to poor performance of the company. It is also important to observe that family firms have an average age of 70 years. It is thus difficult to believe that families sell their shares in times of poor firm performance, or inversely are able to predict the future in a correct way over such a long period of time. It also seems implausible that a family can sell its stake in the company at a good price if it is really performing poorly. Finally, no other study on family firm performance has found that the presence of endogeneity alters the conclusions significantly.

However to confirm these observations, we explicitly test for endogeneity by estimating treatment effect regressions using the two-step procedure developed by Heckman (1979). This procedure necessitates the use of at least one instrumental variable in the first-stage probit model. We use idiosyncratic risk as this variable has been used by several other authors in the literature (Anderson and Reeb (2003), Villalonga and Amit (2006), Miller et al. (2007)). This variable appears to have the requested qualities for a good instrument since it meets the exclusion restriction and is able to predict family firm status. The results of the treatment regressions are presented in Table 8 . They are qualitatively similar to those obtained in Table 4 , since family firms still yield a higher profitability while the market value is not different from those of companies held by other blockholders. Heckman's $\lambda$ is only significant for the ROA regressions while it is insignificant for the Tobin's Q regressions ${ }^{5}$. The impact of endogeneity appears to be modest in our tests and confirms that the intuitive arguments given above are valid.

[Insert Table 8 about here]

The analysis of family firm performance should effectively reflect the link between the specification and attributes. To verify the robustness of the results obtained in the previous sections, several tests are performed. We first analyse whether a bias can arise from

\footnotetext{
${ }^{5} \mathrm{We}$ also estimate the regression with an instrumental variables 2SLS procedure and find similar results to the treatment effect regression. The Heckman procedure is more appropriate since the potentially endogeneous regressor is a dummy variable.
} 
companies that drop out during the sample period. Therefore, we use a balanced sample that comprises 871 firm-year observations for 109 firms. In an unreported analysis, we find that the results are very similar to those obtained initially and that family firms outperform other

firms in terms of profitability. ${ }^{6}$ We also run a year-by-year analysis and find that family firms are always more profitable, while not significantly, every year. Finally, we also test if our results are robust to the definition of accounting performance. We use the ROE instead of the ROA and find qualitatively similar results.

\section{Summary and conclusions}

Theory suggests that classical agency conflicts between managers and shareholders may be reduced for firms with a large shareholder because these have an incentive to control management. This reduction of agency problems should enable a company to create additional value for all shareholders. However, another type of agency problem between majority and minority shareholders may emerge. The extraction of private benefits by the majority shareholder can potentially have a value destroying effect on the firm. Several studies have shown that family firms create value and are more profitable than non-family firms. This evidence is in favour of the idea that agency costs can be reduced significantly by family shareholders. However, these findings do not make a clear distinction among nonfamily firms. These range from firms with a widespread ownership base to companies having a large non-family blockholder.

This paper provides new evidence on the performance of founding family firms. It focuses on the difference in market- and accounting based performance for companies with different ownership structures. It distinguishes founding family firms from companies that either have a non-family blockholder or are widely held. In particular, we want to find out if all companies with a blockholder can mitigate agency costs or if founding family firms have a special characteristic that allows them to outperform other company types beyond the reduction of agency costs. We investigate this issue on a sample of 185 Swiss firms over the period 2003-2010. This market is ideal to address this question as it has a balanced distribution of ownership structures with approximately one-third being family firms, onethird being widely held and the rest having a non-family blockholder.

\footnotetext{
${ }^{6}$ All unreported results are available from the authors upon request.
} 
In general, we find that founding family firms are more profitable than other companies but have similar valuations. This shows that families have the capacity to generate larger profits but that the market does not offer a value premium for these firms. A more detailed analysis reveals that firm characteristics have a significant impact on performance. We find that it is especially firms at the founder stage which are more profitable and have significantly higher valuations. The benefits of family control are most pronounced for firms with lone founders who are active in the firm. Furthermore, our results show that companies in which family control is not contestable show a better performance.

Our results suggest that family control has a positive influence on performance, and that it helps to mitigate agency costs far better than other types of blockholders. These findings indicate that family firms must possess characteristics that allow them to create value for shareholders that other blockholders do not have. Possible explanations include that a founding family cannot afford to either lose out by not controlling management or to treat shareholders poorly by expropriating them. Only a family has a large part of its own wealth invested in the company, and therefore has an incentive to thoroughly control management. In case of other blockholders, its representative is himself only an agent (employee of the blockholder), and thus has much less of an incentive to control others as he does not directly bear the consequences of poor management or decision-making. On the other hand, a family will have difficulties in expropriating minority shareholders as it would put the company in a bad light and as an extension the family itself. Considering the tight-knit connections a family often has with its environment and stakeholders, it cannot and will not want to create a poor reputation. Furthermore, expropriating minority shareholders will complicate future equity issuance or will lead to an undervaluation of the company which will once again directly affect the wealth of family members. It appears that a founding family firm is the only company type in which the owner has an incentive both to mitigate agency costs I and not to expropriate stakeholders (minimisation of agency costs II). 


\section{References}

Anderson, R.C., Reeb, D.M., 2003. Founding-Family Ownership and Firm Performance: Evidence from the S\&P 500. Journal of Finance 58, 1301-1327.

Andres, C., 2008. Large Shareholders and Firm Performance: An Empirical Examination of Founding-Family Ownership. Journal of Corporate Finance 14, 431-445.

Arregle, J.L., Hitt, M.A., Sirmon, D.G., Very, P., 2007. The Development of Organizational Social Capital: Attributes of Family Firms. Journal of Management Studies 44, 73-95.

Barontini, R., Caprio, L., 2006. The Effect of Family Control on Firm Value and Performance: Evidence from Continental Europe. European Financial Management 12, 689723.

Bennedsen, M., Nielsen, K.M., Pérez-González, F., Wolfenzon, D., 2007. Inside the Family Firm: the Role of Families in Succession Decisions and Performance. Quarterly Journal of Economics 122, 647-691.

Berle, A., Means, G., 1932. The Modern Corporation and Private Property. Macmillan, New York.

Claessens, S., Djankov, S., Lang, L.H.P., 2000. The Separation of Ownership and Control in East Asian Corporations. Journal of Financial Economics 58, 81-112.

Corbetta, G., Salvato, C., 2004. Self-Serving or Self-Actualizing? Models of Man and Agency Costs in Different Types of Family Firms: A Commentary on "Comparing the Agency Costs of Family and Non-family Firms: Conceptual Issues and Exploratory Evidence”. Entrepreneurship Theory and Practice 28, 355-362.

Cronqvist, H., Nilsson, M., 2003. Agency Costs of Controlling Minority Shareholders. Journal of Financial and Quantitative Analysis 38, 695-719.

DeAngelo, H., DeAngelo, L., 2000. Controlling Stockholders and the Disciplinary Role of Corporate Payout Policy: A Study of the Times Mirror Company. Journal of Financial Economics 56, 153-207.

Demsetz, H., 1983. The Structure of Ownership and the Theory of the Firm. Journal of Law and Economics 26, 375-390.

Demsetz, H., Villalonga, B., 2001. Ownership Structure and Corporate Performance. Journal of Corporate Finance 7, 209-233.

Dyck, A., Zingales, L., 2004. Private Benefits of Control: An International Comparison. Journal of Finance 59, 537-600. 
Faccio, M., Lang, L.H.P., 2002. The Ultimate Ownership of Western European Corporations. Journal of Financial Economics 65, 365-395.

Fahlenbrach, R., 2009. Founder-CEOs, Investment Decisions, and Stock Market Performance. Journal of Financial and Quantitative Analysis 44, 439-466.

Grossman, S., Hart, O., 1980. Takeover Bids, the Free-Rider Problem, and the Theory of the Corporation. Bell Journal of Economics 11, 42-64.

Heckman, J.J., 1979. Sample Selection Bias as a Specification Error. Econometrica 47, 153161.

Himmelberg, C.P., Hubbard, R.G., Palia, D., 1999. Understanding the Determinants of Managerial Ownership and the Link between Ownership and Performance. Journal of Financial Economics 53, 353-384.

Jensen, M.C., Meckling, W.H., 1976. Theory of the Firm: Managerial Behavior, Agency Costs and Ownership Structure. Journal of Financial Economics 3, 305-360.

King, M.R., Santor, E., 2008. Family Values: Ownership Structure, Performance and Capital Structure of Canadian firms. Journal of Banking and Finance 32, 2423-2432.

Kunz, R., 2002. Simplification of Equity Capital Structure and Market Value. Financial Markets and Portfolio Management 16, 30-52.

La Porta, R., Lopez-de-Silanes, F., Shleifer, A., 1999. Corporate Ownership around the World. Journal of Finance 54, 471-517.

Maury, B., 2006. Family Ownership and Firm Performance: Empirical Evidence from Western European Corporations. Journal of Corporate Finance 12, 321-341.

Miller, D., Le Breton-Miller, I., 2005. Managing for the Long Run: Lessons in Competitive Advantage from Great Family Businesses. Harvard Business School Press Boston.

Miller, D., Le Breton-Miller, I., Lester, R.H., Cannella Jr, A.A., 2007. Are Family Firms Really Superior Performers? Journal of Corporate Finance 13, 829-858.

Morck, R., Shleifer, A., Vishny, R.W., 1988. Management Ownership and Market Valuation:: An Empirical Analysis. Journal of Financial Economics 20, 293-315.

Pérez-González, F., 2006. Inherited Control and Firm Performance. American Economic Review 96, 1559-1588.

Schulze, W.S., Lubatkin, M.H., Dino, R.N., 2003. Toward a Theory of Agency and Altruism in Family Firms. Journal of Business Venturing 18, 473-490.

Shleifer, A., Vishny, R.W., 1997. A Survey of Corporate Governance. Journal of Finance 52, $737-783$ 
Sraer, D., Thesmar, D., 2007. Performance and Behavior of Family Firms: Evidence from the French Stock Market. Journal of the European Economic Association 5, 709-751.

Villalonga, B., Amit, R., 2006. How do Family Ownership, Control and Management Affect Firm Value? Journal of Financial Economics 80, 385-417.

Ward, J.L., 2004. Perpetuating the Family Business: 50 Lessons Learned from Long-lasting, Successful Families in Business. Palgrave Macmillan, Basingstoke. 
Table 1

Number and Percentage of Firm-years for each Industry and Ownership Type

\begin{tabular}{|c|c|c|c|c|c|c|c|c|c|c|}
\hline $\begin{array}{l}\text { IC B } \\
\text { Code }\end{array}$ & Industry Description & All firms & $\begin{array}{l}\text { Widely } \\
\text { Held }\end{array}$ & $\begin{array}{l}\text { Family } \\
\text { Firm }\end{array}$ & $\begin{array}{l}\text { Private } \\
\text { Investor }\end{array}$ & State & $\begin{array}{c}\text { WH } \\
\text { Corporation }\end{array}$ & $\begin{array}{c}\text { WH } \\
\text { Financial }\end{array}$ & Misc. & $\begin{array}{c}\text { Family Firms } \\
\text { in industry } \\
(\%)\end{array}$ \\
\hline 530 & Oil \& Gas Producers & 5 & 4 & 0 & 0 & 0 & 0 & 1 & 0 & $0.00 \%$ \\
\hline 1350 & Chemicals & 65 & 43 & 22 & 0 & 0 & 0 & 0 & 0 & $33.84 \%$ \\
\hline 1730 & Forestry \& Paper & 29 & 15 & 8 & 6 & 0 & 0 & 0 & 0 & $27.61 \%$ \\
\hline 1750 & Industrial Metals \& Mining & 24 & 3 & 8 & 8 & 0 & 0 & 5 & 0 & $33.40 \%$ \\
\hline 2350 & Construction \& Materials & 74 & 29 & 30 & 13 & 0 & 0 & 0 & 2 & $40.53 \%$ \\
\hline 2720 & General Industrials & 22 & 3 & 19 & 0 & 0 & 0 & 0 & 0 & $86.43 \%$ \\
\hline 2730 & Electronic \& Electrical Equipment & 77 & 36 & 21 & 14 & 0 & 0 & 6 & 0 & $27.26 \%$ \\
\hline 2750 & Industrial Engineering & 207 & 78 & 85 & 32 & 0 & 3 & 8 & 1 & $41.06 \%$ \\
\hline 2770 & Industrial Transportation & 32 & 0 & 8 & 10 & 8 & 0 & 0 & 6 & $25.04 \%$ \\
\hline 2790 & Support Services & 32 & 3 & 10 & 6 & 8 & 5 & 0 & 0 & $31.26 \%$ \\
\hline 3350 & Automobiles \& Parts & 6 & 0 & 6 & 0 & 0 & 0 & 0 & 0 & $100.00 \%$ \\
\hline 3530 & Beverages & 4 & 0 & 4 & 0 & 0 & 0 & 0 & 0 & $100.00 \%$ \\
\hline 3570 & Food Producers & 63 & 19 & 16 & 0 & 0 & 5 & 0 & 23 & $25.38 \%$ \\
\hline 3720 & $\begin{array}{l}\text { Household Goods \& Home } \\
\text { Construction }\end{array}$ & 36 & 10 & 10 & 15 & 0 & 0 & 1 & 0 & $27.77 \%$ \\
\hline 3740 & Leisure Goods & 6 & 0 & 6 & 0 & 0 & 0 & 0 & 0 & $100.00 \%$ \\
\hline 3760 & Personal Goods & 30 & 0 & 24 & 6 & 0 & 0 & 0 & 0 & $80.00 \%$ \\
\hline 4530 & Health Care Equipment \& Services & 68 & 27 & 41 & 0 & 0 & 0 & 0 & 0 & $60.29 \%$ \\
\hline 4570 & Pharmaceuticals \& Biotechnology & 82 & 50 & 26 & 2 & 0 & 2 & 2 & 0 & $31.70 \%$ \\
\hline 5330 & Food \& Drug Retailers & 17 & 8 & 0 & 0 & 0 & 9 & 0 & 0 & $0.00 \%$ \\
\hline 5370 & General Retailers & 44 & 12 & 10 & 14 & 0 & 1 & 7 & 0 & $22.73 \%$ \\
\hline 5550 & Media & 40 & 16 & 16 & 0 & 8 & 0 & 0 & 0 & $40.01 \%$ \\
\hline 5750 & Travel \& Leisure & 63 & 18 & 14 & 7 & 8 & 5 & 5 & 6 & $22.23 \%$ \\
\hline 6530 & Fixed Line T elecommunications & 8 & 0 & 0 & 0 & 8 & 0 & 0 & 0 & $0.00 \%$ \\
\hline 7530 & Electricity & 40 & 3 & 0 & 0 & 21 & 16 & 0 & 0 & $0.00 \%$ \\
\hline 9530 & Software \& Computer Services & 54 & 20 & 31 & 2 & 0 & 0 & 1 & 0 & $57.38 \%$ \\
\hline 9570 & Technology Hardware \& Equipment & 65 & 42 & 16 & 2 & 0 & 0 & 5 & 0 & $24.60 \%$ \\
\hline & Total & 1193 & 439 & 431 & 137 & 61 & 46 & 41 & 38 & $36.13 \%$ \\
\hline
\end{tabular}

Family firm is defined as founding families or individuals holding more than $20 \%$ of voting rights. A $20 \%$ ownership level is also used for the remaining ownership types (Private Investor, State, Widely held (WH) Corporation, WH Financial and Miscellaneous). A private investor is a private person that did not found the company. Widely held firms do not have any shareholder holding of $20 \%$ or more voting rights. The sample contains 1193 firm-year observations taken from 185 firms included in the Swiss Performance Index for the period 2003-2010. 
Table 2

Descriptive Statistics

\begin{tabular}{|c|c|c|c|c|c|}
\hline & Mean & Median & $\begin{array}{l}\text { Standard } \\
\text { deviation }\end{array}$ & Maximum & Minimum \\
\hline Tobin's Q & 1.66 & 1.33 & 1.02 & 9.09 & 0.30 \\
\hline ROA (in \%) & 6.58 & 7.32 & 10.64 & 35.11 & -75.15 \\
\hline Return on Equity (in \%) & 9.42 & 10.69 & 22.38 & 235.99 & -163.91 \\
\hline Wedge & 0.05 & 0.00 & 0.11 & 0.66 & -0.05 \\
\hline Firm size (total as sets in CHF 000) & 3'599'691 & $477^{\prime} 068$ & $12^{\prime} 676^{\prime} 092$ & $122^{\prime} 360^{\prime} 689$ & $12^{\prime} 483$ \\
\hline Firm age (in years since inception) & 69.92 & 55.00 & 61.09 & 492.00 & 1.00 \\
\hline Leverage (in \%) & 54.43 & 34.12 & 76.01 & 833.84 & 0.00 \\
\hline Sales growth (in \%) & 6.84 & 3.86 & 39.37 & 659.40 & -99.75 \\
\hline Investment intensity (in \%) & 19.04 & 14.90 & 16.56 & 193.11 & 0.00 \\
\hline Beta & 1.02 & 0.90 & 0.70 & 6.12 & -1.72 \\
\hline Family firm $20-50 \%$ stake & 0.14 & 0.00 & 0.35 & 1.00 & 0.00 \\
\hline Family Firm $>50 \%$ stake & 0.22 & 0.00 & 0.41 & 1.00 & 0.00 \\
\hline Widely Held & 0.37 & 0.00 & 0.48 & 1.00 & 0.00 \\
\hline Founding family firm & 0.36 & 0.00 & 0.48 & 1.00 & 0.00 \\
\hline Family firm (founder stage) & 0.13 & 0.00 & 0.34 & 1.00 & 0.00 \\
\hline Family firm (descendant stage) & 0.23 & 0.00 & 0.42 & 1.00 & 0.00 \\
\hline Private Investor & 0.11 & 0.00 & 0.32 & 1.00 & 0.00 \\
\hline State & 0.05 & 0.00 & 0.22 & 1.00 & 0.00 \\
\hline WH Corporation & 0.04 & 0.00 & 0.19 & 1.00 & 0.00 \\
\hline WH Financial & 0.03 & 0.00 & 0.18 & 1.00 & 0.00 \\
\hline Mis cellaneous & 0.03 & 0.00 & 0.18 & 1.00 & 0.00 \\
\hline \multicolumn{6}{|c|}{$\begin{array}{l}\text { The variables for the analysed sample of } 185 \text { firms and } 1193 \text { firm-year observations include Tobin's Q, ROA, } \\
\text { ROE, the wedge (difference between voting and ownership rights), firm size, firm age, leverage (total } \\
\text { debt/total equity), one-year sales growth, investment intensity (capex/PPE) and beta (calculated with returns } \\
\text { over the previous } 60 \text { months). Variables related to the ownership structure (founding family firm, private } \\
\text { investor, state, widely held (WH) corporation, WH financial and miscellaneous) denote a dummy taking the } \\
\text { value } 1 \text {, if the firm has this kind of blockholder with } 20 \% \text { or more voting rights. Family firm }(20-50 \% ;>50 \% \text { ) } \\
\text { indicate a dummy equalling } 1 \text {, if the founding family holds a stake of } 20-50 \% \text { or more than } 50 \% \text { in the family } \\
\text { company, respectively. Family firm (founder and descendant stage) designate a dummy equalling } 1 \text {, if the } \\
\text { founding family is controlled by a founder or by descendants of the founder, respectively. Widely held denotes } \\
\text { firms in which no shareholder has at least } 20 \% \text { of voting rights. }\end{array}$} \\
\hline
\end{tabular}


Table 3

Univariate Tests

\begin{tabular}{|c|c|c|c|c|c|c|c|c|c|}
\hline Panel A: Test of means & All firms & Family firm & $\begin{array}{c}\text { Family firm } \\
\text { management }\end{array}$ & $\begin{array}{c}\text { Other } \\
\text { blockholder }\end{array}$ & $\begin{array}{c}\text { Widely } \\
\text { Held }\end{array}$ & $\begin{array}{c}\text { Family vs. } \\
\text { Family Mgmt }\end{array}$ & $\begin{array}{c}\text { Family vs. } \\
\text { Widely held }\end{array}$ & $\begin{array}{c}\text { Family vs. } \\
\text { Other blockholder }\end{array}$ & $\begin{array}{c}\text { Other blockholder } \\
\text { vs. Widely held }\end{array}$ \\
\hline & Mean & Mean & Mean & Mean & Mean & t-stat & t-stat & t-stat & t-stat \\
\hline Tobin's Q & 1.66 & 1.70 & 1.76 & 1.45 & 1.78 & -0.75 & -1.02 & $3.87 * * *$ & $-4.91 * * *$ \\
\hline ROA (in \%) & 6.58 & 7.92 & 7.88 & 5.70 & 5.92 & 0.07 & $2.63 * * *$ & $3.71 * * *$ & -0.27 \\
\hline Return on Equity (in \% ) & 9.42 & 12.20 & 12.08 & 8.15 & 7.62 & 0.07 & $2.95 * * *$ & $2.61 * * *$ & 0.33 \\
\hline Wedge & 0.05 & 0.11 & 0.10 & 0.03 & 0.00 & 0.68 & $14.95 * * *$ & $9.46 * * *$ & $6.11 * * *$ \\
\hline Firm size (total assets in CHF 000) & $3^{\prime} 599^{\prime} 691$ & $3^{\prime} 235^{\prime} 442$ & $1^{\prime} 6400^{\prime} 451$ & $1^{\prime} 558^{\prime} 027$ & $5^{\prime} 459^{\prime} 482$ & $3.09 * * *$ & $-2.25 * *$ & $3.22 * * *$ & $-4.47 * * *$ \\
\hline Firm age (in years since inception) & 69.92 & 68.47 & 62.51 & 88.97 & 57.32 & $1.72 *$ & $3.31 * * *$ & $-4.10 * * *$ & $6.09 * * *$ \\
\hline Leverage (in \% ) & 54.43 & 53.55 & 54.57 & 66.90 & 46.11 & -0.15 & 1.44 & $-2.22 * *$ & $4.11 * * *$ \\
\hline Sales growth (in \%) & 6.84 & 6.07 & 6.96 & 6.61 & 7.76 & -0.30 & -0.59 & -0.23 & -0.40 \\
\hline Inves tment intensity (in \% ) & 19.04 & 18.77 & 19.62 & 16.44 & 21.23 & -0.75 & $-2.20 * *$ & $2.05^{* *}$ & $-3.78 * * *$ \\
\hline Beta & 1.02 & 0.98 & 1.00 & 0.82 & 1.20 & -0.45 & $-4.79 * * *$ & $3.26 * * *$ & $-6.99 * * *$ \\
\hline Observations & 1193 & 431 & 294 & 323 & 439 & & & & \\
\hline
\end{tabular}

\begin{tabular}{|c|c|c|c|c|c|c|c|c|c|}
\hline Panel B: Test of medians & All firms & Family firm & $\begin{array}{c}\text { Family firm } \\
\text { management }\end{array}$ & $\begin{array}{c}\text { Other } \\
\text { blockholder }\end{array}$ & $\begin{array}{l}\text { Widely } \\
\text { Held }\end{array}$ & $\begin{array}{c}\text { Family vs. } \\
\text { Family Mgmt }\end{array}$ & $\begin{array}{c}\text { Family vs. } \\
\text { Widely held }\end{array}$ & $\begin{array}{c}\text { Family vs. } \\
\text { Other blockholder }\end{array}$ & $\begin{array}{c}\text { Other blockholder } \\
\text { vs. Widely held }\end{array}$ \\
\hline & Median & Median & Median & Median & Median & & & & \\
\hline Tobin's Q & 1.33 & 1.38 & 1.50 & 1.21 & 1.40 & $-3.30 * * *$ & -1.11 & $4.25^{* * *}$ & $-5.26 * * *$ \\
\hline ROA (in \%) & 7.32 & 8.37 & 8.64 & 6.26 & 7.82 & -0.62 & 1.16 & $5.01 * * *$ & $-3.15 * * *$ \\
\hline Return on Equity (in \% ) & 10.69 & 11.87 & 12.64 & 8.80 & 10.81 & -1.19 & $1.72 *$ & $3.54 * * *$ & -1.53 \\
\hline Wedge & 0.00 & 0.00 & 0.00 & 0.00 & 0.00 & 1.32 & $14.44 * * *$ & $8.02 * * *$ & $7.64 * * *$ \\
\hline Firm size (total assets in CHF 000) & $477^{\prime} 068$ & $556 ' 223$ & $475^{\prime} 532$ & $468^{\prime} 434$ & $437^{\prime} 900$ & $1.97 * *$ & 0.98 & 1.11 & 0.29 \\
\hline Firm age (in years since inception) & 55.00 & 68.00 & 48.00 & 95.00 & 32.00 & $4.50 * * *$ & $4.54 * * *$ & $-3.40 * * *$ & $6.05 * * *$ \\
\hline Leverage (in \% ) & 34.12 & 26.89 & 25.72 & 46.39 & 32.40 & 1.40 & -0.72 & $-4.43 * * *$ & $4.12 * * *$ \\
\hline Sales growth (in \% ) & 3.86 & 4.73 & 4.85 & 4.71 & 2.35 & -0.55 & 1.52 & -0.39 & $1.65^{*}$ \\
\hline Inves tment intensity (in \% ) & 14.90 & 16.42 & 17.11 & 12.21 & 15.87 & $-1.82 *$ & -0.98 & $3.98 * * *$ & $-5.01 * * *$ \\
\hline Beta & 0.90 & 0.90 & 0.90 & 0.66 & 1.15 & -0.17 & $-4.36 * * *$ & $4.79 * * *$ & $-7.52 * * *$ \\
\hline Observations & 1193 & 431 & 294 & 323 & 439 & & & & \\
\hline
\end{tabular}

The variables for the analysed sample of 185 firms and 1193 firm-year observations include Tobin's Q, ROA, the wedge, firm size, firm age, leverage, one-year sales growth, investment intensity and beta. Tests are performed on the difference of means (Panel A) and medians (Panel B:Wilcoxon-Mann-Whitney test) between family vs. family managed firms, family companies vs. widely held firms, family companies vs. firms with other blockholder types and widely held vs. companies with non-family blockholders.

$* * *, * *, *$ show significance at the $1 \%, 5 \%, 10 \%$ levels, respectively. 
Table 4

Performance and Family Ownership

\begin{tabular}{|c|c|c|c|c|}
\hline & \multicolumn{2}{|c|}{ ln (Tobin's Q) } & \multicolumn{2}{|c|}{ ROA } \\
\hline & (1) & (2) & (3) & (4) \\
\hline Founding family & 0.079 & & $2.825 * * *$ & \\
\hline & $(1.26)$ & & $(2.66)$ & \\
\hline Family stake & & $\begin{array}{c}0.770 * * \\
(2.46)\end{array}$ & & $\begin{array}{c}14.641 * * * \\
(2.80)\end{array}$ \\
\hline (Family stake) $^{2}$ & & $\begin{array}{c}-1.026 * * \\
(-2.57)\end{array}$ & & $\begin{array}{c}-14.679 * * \\
(-2.32)\end{array}$ \\
\hline Wedge & $\begin{array}{c}-0.431^{*} \\
(-1.84)\end{array}$ & $\begin{array}{l}-0.268 \\
(-1.37)\end{array}$ & $\begin{array}{l}-3.415 \\
(-1.03)\end{array}$ & $\begin{array}{l}-2.806 \\
(-0.93)\end{array}$ \\
\hline Ln (firm size) & $\begin{array}{c}0.065 * * * \\
\quad(4.23)\end{array}$ & $\begin{array}{c}0.062 * * * \\
\quad(4.04)\end{array}$ & $\begin{array}{c}1.681 * * * \\
(5.18)\end{array}$ & $\begin{array}{c}1.658 * * * \\
(5.15)\end{array}$ \\
\hline Ln (firm age) & $\begin{array}{l}-0.000 \\
(-0.00)\end{array}$ & $\begin{array}{l}-0.002 \\
(-0.06)\end{array}$ & $\begin{array}{l}0.879 \\
(1.47)\end{array}$ & $\begin{array}{l}0.885 \\
(1.48)\end{array}$ \\
\hline Leverage & $\begin{array}{l}-0.000 \\
(-1.42)\end{array}$ & $\begin{array}{l}-0.000 \\
(-1.28)\end{array}$ & $\begin{array}{c}-0.013 * * * \\
(-2.61)\end{array}$ & $\begin{array}{c}-0.013 * * * \\
(-2.63)\end{array}$ \\
\hline 1-year sales growth & $\begin{array}{c}0.001 * \\
(1.66)\end{array}$ & $\begin{array}{l}0.001 \\
(1.60)\end{array}$ & $\begin{array}{l}0.022 \\
(1.09)\end{array}$ & $\begin{array}{l}0.022 \\
(1.09)\end{array}$ \\
\hline Inves tment intensity & $\begin{array}{c}0.007 * * * \\
(3.88)\end{array}$ & $\begin{array}{c}0.007 * * * \\
(3.84)\end{array}$ & $\begin{array}{c}0.112 * * \\
(2.47)\end{array}$ & $\begin{array}{c}0.112 * * \\
(2.47)\end{array}$ \\
\hline Beta & $\begin{array}{l}0.006 \\
(0.18)\end{array}$ & $\begin{array}{l}0.001 \\
(0.02)\end{array}$ & $\begin{array}{c}-1.490 * \\
(-1.83)\end{array}$ & $\begin{array}{c}-1.470 * \\
(-1.79)\end{array}$ \\
\hline Widely held & $\begin{array}{l}0.055 \\
(0.97)\end{array}$ & $\begin{array}{l}0.071 \\
(1.26)\end{array}$ & $\begin{array}{l}1.063 \\
(0.97)\end{array}$ & $\begin{array}{l}1.294 \\
(1.19)\end{array}$ \\
\hline Constant & $\begin{array}{c}-1.157 * * * \\
(-4.63)\end{array}$ & $\begin{array}{c}-1.108 * * * \\
(-4.53)\end{array}$ & $\begin{array}{c}-27.676^{* * * *} \\
(-4.56)\end{array}$ & $\begin{array}{c}-27.615 * * * \\
(-4.56)\end{array}$ \\
\hline Indus try Dummies & Yes & Yes & Yes & Yes \\
\hline Year Dummies & Yes & Yes & Yes & Yes \\
\hline Observations & 1183 & 1183 & 1183 & 1183 \\
\hline Adj. R-s quared & 0.32 & 0.33 & 0.14 & 0.14 \\
\hline Inflection point (\%) & & $39.50 \%$ & & $49.90 \%$ \\
\hline
\end{tabular}

The variables for the analysed sample of 185 firms and 1193 firm-year observations include Tobin's Q, ROA, the wedge (difference between voting and ownership rights), firm size, firm age, leverage (total debt/total equity), one-year sales growth, investment intensity (capex/PPE) and beta. Founding family denotes a dummy taking the value 1 if the founding family holds at least $20 \%$ of voting rights in the firm. Family stake and (Family stake) $)^{2}$ indicate the stake and the stake squared that the founding family, respectively, holds in the company. The $t$-stats are in parentheses and are calculated with clustered robust standard errors.

$* * *, * *, *$ show significance at the $1 \%, 5 \%, 10 \%$ levels, respectively. 
Table 5

Family Ownership and Active Involvement

\begin{tabular}{|c|c|c|c|c|c|c|}
\hline & \multicolumn{3}{|c|}{ In(Tobin's Q) } & \multicolumn{3}{|c|}{ ROA } \\
\hline & (1) & (2) & (3) & (4) & (5) & (6) \\
\hline Family - active & $\begin{aligned} 0.117^{*} \\
(1.80)\end{aligned}$ & & & $\begin{array}{l}3.017 * * * \\
(2.66)\end{array}$ & & \\
\hline Family CEO \& CoB & & $\begin{array}{l}0.122 \\
(1.36)\end{array}$ & & & $\begin{array}{c}3.802 * * \\
(2.45)\end{array}$ & \\
\hline Family CEO & & $\begin{array}{l}0.066 \\
(0.76)\end{array}$ & & & $\begin{array}{c}3.155^{* *} \\
(2.01)\end{array}$ & \\
\hline Family CoB & & $\begin{array}{l}0.132 \\
(1.62)\end{array}$ & & & $\begin{array}{l}2.650 * * \\
(2.02)\end{array}$ & \\
\hline Founder active alone & & & $\begin{array}{r}0.183^{*} \\
(1.91)\end{array}$ & & & $\begin{array}{c}4.504 * * \\
(2.26)\end{array}$ \\
\hline Descendant active alone & & & $\begin{array}{l}0.072 \\
(0.98)\end{array}$ & & & $\begin{array}{l}1.989^{*} \\
(1.84)\end{array}$ \\
\hline $\begin{array}{l}\text { Founder and Descendant } \\
\text { active }\end{array}$ & & & $\begin{array}{l}0.184 \\
(1.16)\end{array}$ & & & $\begin{array}{c}4.651 * * * \\
(3.95)\end{array}$ \\
\hline No family active & $\begin{array}{l}-0.011 \\
(-0.13)\end{array}$ & $\begin{array}{l}-0.013 \\
(-0.14)\end{array}$ & $\begin{array}{l}-0.016 \\
(-0.18)\end{array}$ & $\begin{array}{r}2.372^{*} \\
(1.75)\end{array}$ & $\begin{array}{r}2.403^{*} \\
(1.76)\end{array}$ & $\begin{array}{r}2.268^{*} \\
(1.67)\end{array}$ \\
\hline Wedge & $\begin{array}{r}-0.413^{*} \\
(-1.76)\end{array}$ & $\begin{array}{r}-0.391^{*} \\
(-1.69)\end{array}$ & $\begin{array}{l}-0.374 \\
(-1.60)\end{array}$ & $\begin{array}{l}-3.326 \\
(-0.99)\end{array}$ & $\begin{array}{l}-3.767 \\
(-1.11)\end{array}$ & $\begin{array}{l}-2.437 \\
(-0.76)\end{array}$ \\
\hline Ln(firm size) & $\begin{array}{c}0.067 * * * \\
(4.42)\end{array}$ & $\begin{array}{c}0.066 * * * \\
(4.38)\end{array}$ & $\begin{array}{c}0.067 * * * \\
(4.39)\end{array}$ & $\begin{array}{l}1.689 * * * \\
(5.18)\end{array}$ & $\begin{array}{l}1.701 * * * \\
(5.16)\end{array}$ & $\begin{array}{c}1.686 * * * \\
(5.12)\end{array}$ \\
\hline Ln(firm age) & $\begin{array}{l}0.004 \\
(0.16)\end{array}$ & $\begin{array}{l}0.003 \\
(0.12)\end{array}$ & $\begin{array}{l}0.012 \\
(0.42)\end{array}$ & $\begin{array}{l}0.901 \\
(1.49)\end{array}$ & $\begin{array}{l}0.923 \\
(1.51)\end{array}$ & $\begin{array}{l}1.074 \\
(1.60)\end{array}$ \\
\hline Leverage & $\begin{array}{l}-0.000 \\
(-1.47)\end{array}$ & $\begin{array}{l}-0.000 \\
(-1.50)\end{array}$ & $\begin{array}{l}-0.000 \\
(-1.34)\end{array}$ & $\begin{array}{l}-0.013 * * * \\
(-2.60)\end{array}$ & $\begin{array}{c}-0.013 * * \\
(-2.60)\end{array}$ & $\begin{array}{c}-0.013 * * \\
(-2.48)\end{array}$ \\
\hline 1-year sales growth & $\begin{array}{l}0.001 \\
(1.64)\end{array}$ & $\begin{array}{l}0.001 \\
(1.62)\end{array}$ & $\begin{array}{r}0.001^{*} \\
(1.70)\end{array}$ & $\begin{array}{l}0.022 \\
(1.09)\end{array}$ & $\begin{array}{l}0.022 \\
(1.09)\end{array}$ & $\begin{array}{l}0.022 \\
(1.11)\end{array}$ \\
\hline Inves tment intensity & $\begin{array}{c}0.007 * * * \\
(3.86)\end{array}$ & $\begin{array}{c}0.007 * * * \\
(3.85)\end{array}$ & $\begin{array}{c}0.007 * * * \\
(3.83)\end{array}$ & $\begin{array}{c}0.112 * * \\
(2.46)\end{array}$ & $\begin{array}{c}0.112 * * \\
(2.46)\end{array}$ & $\begin{array}{c}0.110^{* *} \\
(2.43)\end{array}$ \\
\hline Beta & $\begin{array}{l}0.004 \\
(0.14)\end{array}$ & $\begin{array}{l}0.003 \\
(0.12)\end{array}$ & $\begin{array}{l}0.002 \\
(0.05)\end{array}$ & $\begin{array}{r}-1.496^{*} \\
(-1.83)\end{array}$ & $\begin{array}{r}-1.505^{*} \\
(-1.84)\end{array}$ & $\begin{array}{r}-1.558^{*} \\
(-1.90)\end{array}$ \\
\hline Widely held & $\begin{array}{l}0.055 \\
(0.97)\end{array}$ & $\begin{array}{l}0.056 \\
(0.99)\end{array}$ & $\begin{array}{l}0.061 \\
(1.09)\end{array}$ & $\begin{array}{l}1.064 \\
(0.98)\end{array}$ & $\begin{array}{l}1.069 \\
(0.98)\end{array}$ & $\begin{array}{l}1.201 \\
(1.10)\end{array}$ \\
\hline Constant & $\begin{array}{c}-1.191 * * * \\
(-4.81)\end{array}$ & $\begin{array}{c}-1.177 * * * \\
(-4.74)\end{array}$ & $\begin{array}{c}-1.215^{* * *} * \\
(-4.75)\end{array}$ & $\begin{array}{c}-27.844 * * * \\
(-4.56)\end{array}$ & $\begin{array}{c}-28.116^{* * *} \\
(-4.54)\end{array}$ & $\begin{array}{c}-28.382 * * * \\
(-4.46)\end{array}$ \\
\hline $\begin{array}{l}\text { Indus try Dummies } \\
\text { Year Dummies }\end{array}$ & $\begin{array}{l}\text { Yes } \\
\text { Yes }\end{array}$ & $\begin{array}{l}\text { Yes } \\
\text { Yes }\end{array}$ & $\begin{array}{l}\text { Yes } \\
\text { Yes }\end{array}$ & $\begin{array}{l}\text { Yes } \\
\text { Yes }\end{array}$ & $\begin{array}{l}\text { Yes } \\
\text { Yes }\end{array}$ & $\begin{array}{l}\text { Yes } \\
\text { Yes }\end{array}$ \\
\hline Observations & 1183 & 1183 & 1183 & 1183 & 1183 & 1183 \\
\hline Adj. R-squared & 0.33 & 0.33 & 0.33 & 0.14 & 0.14 & 0.14 \\
\hline
\end{tabular}

The variables for the analysed sample of 185 firms and 1193 firm-year observations include Tobin's Q, ROA, the wedge (difference between voting and ownership rights), firm size and age, leverage (total debt/total equity), one-year sales growth, investment intensity (capex/PPE) and beta. Family active denotes a dummy taking the value 1 if a member of the founding family is active in the company. Family CEO \& chairman (CoB), CEO, $\mathrm{CoB}$ and no family active indicate a dummy variable taking the value 1 if a family member is either CEO \& $\mathrm{CoB}, \mathrm{CEO}$ only, $\mathrm{CoB}$ only or if there is no active family member. Founder or descendant active alone and founder and descendant active denote a dummy equalling 1 if the founder or the descendant or both are active in the company. The $t$-stats are in parentheses and are calculated with clustered robust standard errors.

$* * *, * *, *$ shows significance at the $1 \%, 5 \%, 10 \%$ level respectively 
Table 6

Family Ownership and Generations

\begin{tabular}{|c|c|c|c|c|c|c|}
\hline & \multicolumn{3}{|c|}{ In (Tobin's Q) } & \multicolumn{3}{|c|}{ ROA } \\
\hline & (1) & (2) & (3) & (4) & (5) & (6) \\
\hline Founder-stage family firm & $\begin{array}{c}0.140^{*} \\
(1.70)\end{array}$ & & & $\begin{array}{c}4.043 * * \\
(2.46)\end{array}$ & & \\
\hline Descendant-s tage family firm & $\begin{array}{l}0.038 \\
(0.50)\end{array}$ & & & $\begin{array}{c}1.997^{*} \\
(1.83)\end{array}$ & & \\
\hline Lone founder firm & & $\begin{array}{r}0.190 * \\
(1.76)\end{array}$ & & & $\begin{array}{c}5.328 * * \\
(2.34)\end{array}$ & \\
\hline Family firm with multiple founders & & $\begin{array}{l}0.060 \\
(0.91)\end{array}$ & & & $\begin{array}{c}2.395 * * \\
(2.33)\end{array}$ & \\
\hline Lone founder or descendant firm & & & $\begin{array}{r}0.183 * \\
(1.91)\end{array}$ & & & $\begin{array}{l}4.298 * * * \\
\quad(2.65)\end{array}$ \\
\hline $\begin{array}{l}\text { Family firms with } \\
\text { multiple family members }\end{array}$ & & & $\begin{array}{l}0.037 \\
(0.57)\end{array}$ & & & $\begin{array}{c}2.229 * * \\
(2.06)\end{array}$ \\
\hline Wedge & $\begin{array}{l}-0.365 \\
(-1.50)\end{array}$ & $\begin{array}{r}-0.410^{*} \\
(-1.77)\end{array}$ & $\begin{array}{l}-0.365 \\
(-1.58)\end{array}$ & $\begin{array}{l}-2.100 \\
(-0.65)\end{array}$ & $\begin{array}{l}-2.944 \\
(-0.87)\end{array}$ & $\begin{array}{l}-2.481 \\
(-0.73)\end{array}$ \\
\hline Ln (firm size) & $\begin{array}{c}0.065^{* * *} * \\
(4.25)\end{array}$ & $\begin{array}{c}0.065 * * * \\
(4.27)\end{array}$ & $\begin{array}{c}0.065 * * * \\
(4.21)\end{array}$ & $\begin{array}{c}1.675^{* * *} * \\
(5.19)\end{array}$ & $\begin{array}{c}1.674 * * * \\
(5.21)\end{array}$ & $\begin{array}{c}1.676^{* * *} * \\
(5.16)\end{array}$ \\
\hline Ln (firm age) & $\begin{array}{l}0.011 \\
(0.39)\end{array}$ & $\begin{array}{l}0.005 \\
(0.19)\end{array}$ & $\begin{array}{l}0.002 \\
(0.09)\end{array}$ & $\begin{array}{l}1.107 \\
(1.63)\end{array}$ & $\begin{array}{l}0.993 \\
(1.64)\end{array}$ & $\begin{array}{l}0.915 \\
(1.54)\end{array}$ \\
\hline Leverage & $\begin{array}{l}-0.000 \\
(-1.31)\end{array}$ & $\begin{array}{l}-0.000 \\
(-1.35)\end{array}$ & $\begin{array}{c}-0.000^{*} \\
(-1.75)\end{array}$ & $\begin{array}{c}-0.013 * * \\
(-2.52)\end{array}$ & $\begin{array}{c}-0.013 * * \\
(-2.55)\end{array}$ & $\begin{array}{c}-0.014 * * * \\
(-2.69)\end{array}$ \\
\hline 1-year sales growth & $\begin{array}{c}0.001 * \\
(1.72)\end{array}$ & $\begin{array}{c}0.001^{*} \\
(1.72)\end{array}$ & $\begin{array}{l}0.001 \\
(1.57)\end{array}$ & $\begin{array}{c}0.022 \\
(1.11)\end{array}$ & $\begin{array}{l}0.022 \\
(1.11)\end{array}$ & $\begin{array}{l}0.021 \\
(1.07)\end{array}$ \\
\hline Inves tment intensity & $\begin{array}{c}0.007 * * * \\
(3.83)\end{array}$ & $\begin{array}{c}0.007 * * * \\
(3.87)\end{array}$ & $\begin{array}{c}0.007 * * * \\
(3.87)\end{array}$ & $\begin{array}{c}0.110^{* *} \\
(2.44)\end{array}$ & $\begin{array}{c}0.111^{* *} \\
(2.47)\end{array}$ & $\begin{array}{c}0.111^{* *} \\
(2.46)\end{array}$ \\
\hline Beta & $\begin{array}{l}0.005 \\
(0.16)\end{array}$ & $\begin{array}{l}0.006 \\
(0.19)\end{array}$ & $\begin{array}{l}0.005 \\
(0.17)\end{array}$ & $\begin{array}{c}-1.506^{*} \\
(-1.85)\end{array}$ & $\begin{array}{r}-1.483^{*} \\
(-1.82)\end{array}$ & $\begin{array}{r}-1.498^{*} \\
(-1.84)\end{array}$ \\
\hline Widely held & $\begin{array}{l}0.061 \\
(1.08)\end{array}$ & $\begin{array}{l}0.058 \\
(1.02)\end{array}$ & $\begin{array}{l}0.056 \\
(0.98)\end{array}$ & $\begin{array}{l}1.189 \\
(1.08)\end{array}$ & $\begin{array}{l}1.132 \\
(1.03)\end{array}$ & $\begin{array}{l}1.069 \\
(0.98)\end{array}$ \\
\hline Constant & $\begin{array}{c}-1.192 * * * \\
(-4.69)\end{array}$ & $\begin{array}{c}-1.173 * * * \\
(-4.71)\end{array}$ & $\begin{array}{c}-1.154 * * * \\
(-4.54)\end{array}$ & $\begin{array}{c}-28.378 * * * \\
(-4.52)\end{array}$ & $\begin{array}{c}-28.029 * * * \\
\quad(-4.61)\end{array}$ & $\begin{array}{c}-27.623 * * * \\
(-4.53)\end{array}$ \\
\hline Indus try Dummies & Yes & Yes & Yes & Yes & Yes & Yes \\
\hline Year Dummies & Yes & Yes & Yes & Yes & Yes & Yes \\
\hline Observations & 1183 & 1183 & 1183 & 1183 & 1183 & 1183 \\
\hline Adj. R-squared & 0.32 & 0.32 & 0.33 & 0.14 & 0.14 & 0.14 \\
\hline
\end{tabular}

The variables for the analysed sample of 185 firms and 1193 firm-year observations include Tobin's Q, ROA, the wedge (difference between voting and ownership rights), firm size, firm age, leverage (total debt/total equity), one-year sales growth, investment intensity (capex/PPE) and beta. Founder- and descendant-stage family firms indicate a dummy variable taking the value 1 if the company is held by the founder or by the descendants, respectively. Lone founder denotes a dummy equalling 1 if there is only one founder involved. A company with multiple founders indicates a dummy equalling 1 for companies with multiple founders or family members involved. Lone founder and descendant as well as family firm with several members designates a dummy taking the value 1 if a founder or a descendant is alone in the firm and if there are multiple family members or individuals controlling the company, respectively. The $t$-stats are in parentheses and are calculated with clustered robust standard errors.

$* * *, * *, *$ show significance at the $1 \%, 5 \%, 10 \%$ levels, respectively. 
Table 7

Family Ownership and Contestability

\begin{tabular}{|c|c|c|c|c|c|c|}
\hline & \multicolumn{3}{|c|}{ In (Tobin's Q) } & \multicolumn{3}{|c|}{ ROA } \\
\hline & (1) & (2) & (3) & (4) & (5) & (6) \\
\hline Family owning 20-50\% & $\begin{array}{l}0.083 \\
(1.00)\end{array}$ & & & $\begin{array}{l}2.043 \\
(1.49)\end{array}$ & & \\
\hline Family owning more than $50 \%$ & $\begin{array}{l}0.075 \\
(1.06)\end{array}$ & & & $\begin{array}{c}3.551 * * * \\
(3.13)\end{array}$ & & \\
\hline Family firm w/out DCS & & $\begin{array}{l}0.056 \\
(0.77)\end{array}$ & & & $\begin{array}{c}2.564 * * \\
(2.14)\end{array}$ & \\
\hline Family firm with DCS & & $\begin{array}{r}0.149^{*} \\
(1.68)\end{array}$ & & & $\begin{array}{c}3.627 * * \\
(2.25)\end{array}$ & \\
\hline Family is contes table & & & $\begin{array}{l}0.059 \\
(0.69)\end{array}$ & & & $\begin{array}{c}2.409^{*} \\
(1.72)\end{array}$ \\
\hline Family is not contestable & & & $\begin{array}{l}0.091 \\
(1.35)\end{array}$ & & & $\begin{array}{c}3.082 * * * \\
(2.78)\end{array}$ \\
\hline Wedge & $\begin{array}{c}-0.421^{*} \\
(-1.74)\end{array}$ & $\begin{array}{c}-0.634 * * \\
(-2.05)\end{array}$ & $\begin{array}{c}-0.460^{*} \\
(-1.96)\end{array}$ & $\begin{array}{l}-5.219 \\
(-1.55)\end{array}$ & $\begin{array}{l}-5.750 \\
(-1.20)\end{array}$ & $\begin{array}{l}-4.019 \\
(-1.19)\end{array}$ \\
\hline Ln (firm size) & $\begin{array}{c}0.065 * * * \\
(4.21)\end{array}$ & $\begin{array}{c}0.065 * * * \\
(4.26)\end{array}$ & $\begin{array}{c}0.066 * * * \\
(4.27)\end{array}$ & $\begin{array}{c}1.700 * * * \\
(5.26)\end{array}$ & $\begin{array}{c}1.682 * * * \\
(5.18)\end{array}$ & $\begin{array}{c}1.689 * * * \\
(5.20)\end{array}$ \\
\hline Ln (firm age) & $\begin{array}{l}-0.000 \\
(-0.01)\end{array}$ & $\begin{array}{l}0.000 \\
(0.00)\end{array}$ & $\begin{array}{l}0.000 \\
(0.01)\end{array}$ & $\begin{array}{l}0.899 \\
(1.50)\end{array}$ & $\begin{array}{l}0.880 \\
(1.47)\end{array}$ & $\begin{array}{l}0.888 \\
(1.48)\end{array}$ \\
\hline Leverage & $\begin{array}{l}-0.000 \\
(-1.41)\end{array}$ & $\begin{array}{l}-0.000 \\
(-1.34)\end{array}$ & $\begin{array}{l}-0.000 \\
(-1.45)\end{array}$ & $\begin{array}{c}-0.014 * * * \\
(-2.66)\end{array}$ & $\begin{array}{c}-0.013 * * \\
(-2.56)\end{array}$ & $\begin{array}{c}-0.013 * * * \\
(-2.63)\end{array}$ \\
\hline 1-year sales growth & $\begin{array}{l}0.001 \\
(1.65)\end{array}$ & $\begin{array}{c}0.001^{*} \\
(1.67)\end{array}$ & $\begin{array}{c}0.001^{*} \\
(1.67)\end{array}$ & $\begin{array}{l}0.022 \\
(1.10)\end{array}$ & $\begin{array}{l}0.022 \\
(1.09)\end{array}$ & $\begin{array}{l}0.022 \\
(1.09)\end{array}$ \\
\hline Inves tment intensity & $\begin{array}{c}0.007 * * * \\
(3.82)\end{array}$ & $\begin{array}{c}0.007 * * * \\
(3.87)\end{array}$ & $\begin{array}{c}0.007 * * * \\
(3.85)\end{array}$ & $\begin{array}{c}0.114 * * \\
(2.49)\end{array}$ & $\begin{array}{c}0.112 * * \\
(2.47)\end{array}$ & $\begin{array}{c}0.113 * * \\
(2.47)\end{array}$ \\
\hline Beta & $\begin{array}{l}0.005 \\
(0.17)\end{array}$ & $\begin{array}{l}0.006 \\
(0.21)\end{array}$ & $\begin{array}{l}0.007 \\
(0.22)\end{array}$ & $\begin{array}{c}-1.391^{*} \\
(-1.66)\end{array}$ & $\begin{array}{r}-1.482^{*} \\
(-1.81)\end{array}$ & $\begin{array}{c}-1.467^{*} \\
(-1.78)\end{array}$ \\
\hline Widely held & $\begin{array}{l}0.056 \\
(0.97)\end{array}$ & $\begin{array}{l}0.049 \\
(0.85)\end{array}$ & $\begin{array}{l}0.054 \\
(0.95)\end{array}$ & $\begin{array}{l}0.980 \\
(0.90)\end{array}$ & $\begin{array}{l}0.992 \\
(0.90)\end{array}$ & $\begin{array}{l}1.041 \\
(0.95)\end{array}$ \\
\hline Constant & $\begin{array}{c}-1.155^{* * * *} \\
(-4.63)\end{array}$ & $\begin{array}{c}-1.155^{* * * *} \\
(-4.64)\end{array}$ & $\begin{array}{c}-1.165^{* * * *} \\
(-4.69)\end{array}$ & $\begin{array}{c}-28.070 * * * \\
(-4.63)\end{array}$ & $\begin{array}{c}-27.644 * * * \\
(-4.56)\end{array}$ & $\begin{array}{c}-27.840 * * * \\
(-4.57)\end{array}$ \\
\hline Indus try Dummies & Yes & Yes & Yes & Yes & Yes & Yes \\
\hline Year Dummies & Yes & Yes & Yes & Yes & Yes & Yes \\
\hline Observations & 1183 & 1183 & 1183 & 1183 & 1183 & 1183 \\
\hline Adj. R-squared & 0.32 & 0.32 & 0.32 & 0.14 & 0.14 & 0.14 \\
\hline
\end{tabular}

The variables for the analysed sample of 185 firms and 1193 firm-year observations include Tobin's Q, ROA, the wedge (difference between voting and ownership rights), firm size, firm age, leverage (total debt/total equity), one-year sales growth, investment intensity (capex/PPE) and beta. A family owning 20-50\%, family owning more than 50\% indicate a dummy equalling 1 if the company has a family owning 20-50\% or more than $50 \%$ of the stocks, respectively. Family firm with or w/out DCS (dual-class shares) designates a dummy variable taking the value 1 if the company is using dual-class shares or not. A family is contestable or not contestable represents a dummy taking the value 1 if a founding family controls between $20-50 \%$ of voting rights in the presence of a second blockholder or if it does not. The $t$-stats are in parentheses and are calculated with clustered robust standard errors.

$* * *, * *, *$ show significance at the $1 \%, 5 \%, 10 \%$ levels, respectively. 
Table 8

Endogeneity and the Heckman Procedure

\begin{tabular}{|c|c|c|}
\hline & In (Tobin's Q) & ROA \\
\hline Founding family & 0.287 & $30.388 * *$ \\
\hline (ins trumented) & $(-1.02)$ & $(-2.21)$ \\
\hline \multirow[t]{2}{*}{ Wedge } & -0.806 & $-53.219^{*}$ \\
\hline & $(-1.56)$ & $(-1.95)$ \\
\hline \multirow[t]{2}{*}{ Ln (firm size) } & $0.068 * * *$ & $1.987 * * *$ \\
\hline & $(-8.42)$ & $(-5.04)$ \\
\hline \multirow[t]{2}{*}{ Ln(firm age) } & $-0.000 * *$ & -0.010 \\
\hline & $(-2.22)$ & $(-1.33)$ \\
\hline \multirow[t]{2}{*}{ Leverage } & $0.001 * *$ & 0.020 \\
\hline & $(-2.12)$ & $(-0.68)$ \\
\hline \multirow[t]{2}{*}{ 1-year sales growth } & $0.007 * * *$ & $0.106 * *$ \\
\hline & $(-9.32)$ & $(-2.42)$ \\
\hline \multirow[t]{2}{*}{ Inves tment intensity } & 0.010 & -0.946 \\
\hline & $(-0.49)$ & $(-0.96)$ \\
\hline \multirow[t]{2}{*}{ Beta } & $0.056^{*}$ & 1.199 \\
\hline & $(-1.76)$ & $(-1.25)$ \\
\hline \multirow[t]{2}{*}{ Widely held } & 0.004 & $1.403 * *$ \\
\hline & $(-0.29)$ & $(-2.01)$ \\
\hline \multirow[t]{2}{*}{ Constant } & $-1.265 * * *$ & $-41.969 * * *$ \\
\hline & $(-4.60)$ & $(-4.02)$ \\
\hline \multirow[t]{2}{*}{ Heckman's $\lambda$} & -0.124 & $-16.435 * *$ \\
\hline & $(-0.34)$ & $(-2.02)$ \\
\hline Indus try Dummies & Yes & Yes \\
\hline Year Dummies & Yes & Yes \\
\hline Obs ervations & 1183 & 1183 \\
\hline
\end{tabular}

This table presents the results of the treatment regressions of the Heckman (1979) procedure and the selection $(\lambda)$ parameter. The variables for the analysed sample of 185 firms and 1193 firm-year observations include Tobin's Q, ROA, the wedge (difference between voting and ownership rights), firm size, firm age, leverage (total debt/total equity), one-year sales growth, investment intensity (capex/PPE) and beta. Founding family denotes a dummy taking the value 1 if the founding family holds at least $20 \%$ of voting rights in the firm. The $t$-stats are in parentheses and are calculated with clustered robust standard errors.

$* * *, * *, *$ show significance at the $1 \%, 5 \%, 10 \%$ levels, respectively. 


\begin{abstract}
Authors
Dušan ISAKOV

Faculty of Economics and Social Sciences, University of Fribourg, 90 Boulevard de Pérolles, 1700-Fribourg, Switzerland, email: dusan.isakov[at]unifr.ch. More on www.unifr.ch/cgf Jean-Philippe WEISSKOPF

Faculty of Economics and Social Sciences, University of Fribourg, 90 Boulevard de Pérolles, 1700-Fribourg, Switzerland, email: jean-philippe.weisskopf[at]unifr.ch
\end{abstract}

\title{
Abstract
}

This paper examines how family and non-family ownership affects the performance of Swiss listed firms from 2003 to 2010. We distinguish between these two types of controlling shareholders since they have different objectives.

We hypothesise that only family shareholders have a real incentive to reduce agency costs whereas non-family blockholders are similar to widely held companies.

Our results show that family firms are more profitable and sometimes display better market valuations as opposed to companies that are widely held or have a non-family blockholder. We investigate the impact of different features of family firms on performance, and document that the generation of the family, active involvement of the family and contestability of family control play an important role.

\section{Keywords}

founding family firm; active management; founder; ownership structure; firm performance; contestability.

\section{JEL Classification}

G3; G32

\section{Citation proposal}

Isakov Dušan, Weisskopf Jean-Philippe. 2012. «Are Founding Families Special Blockholders? An Investigation of Controlling Shareholder Influence on Firm Performance». Working Papers SES 428, Faculty of Economics and Social Sciences, University of Fribourg (Switzerland)

\section{Working Papers SES}

Last published :

421 Isakov D., Marti D.: Technical Analysis with a Long-Term Perspective: Trading Strategies and Market Timing Ability; 2011

422 Dembinski P.: Encyclical Letter "Caritas in Veritate": An Economist's Reading; 2011

423 Panzera F.: Price stability and financial imbalances: rethinking the macrofinancial framework after the 2007-8 financial crisis; 2011

424 Dafflon B.: The Political Economy of Decentralisation in Sikkim: Strengthening Gram Panchayat Planning and Budgeting; 2011

425 Dafflon B., Daguet S.: Performance measurement in environmental management at the local level: an experiment and proposal with reference to Switzerland; 2012

426 Dafflon B.: Voluntary amalgamation of local governments: the Swiss debate in the European context; 2012

427 Wallmeier M.: Smile in Motion: An Intraday Analysis of Asymmetric Implied Volatility; 2012

\section{Catalogue and download links:}

http://www.unifr.ch/ses/wp

http://doc.rero.ch/collection/UNIFR WORKING_PAPERS SES 